\title{
The Effects of Margin of Appreciation Doctrine on the European Court of Human Rights: Upholding Public Morality over Fundamental Rights
}

\author{
Takdir Hakk Doktrininin Avrupa İnsan Hakları Mahkemesi \\ Üzerindeki Etkisi: Temel Haklara Karşı Kamu Ahlakını \\ Desteklemek
}

\section{Itır Aladağ Görentaş}

\begin{abstract}
The European Court of Human Rights' (the Court, ECtHR) granting opportunity to Contracting States to strike a balance between the public good and the interests of the individuals is designated as "margin of appreciation doctrine". Unfortunately, the Court is facing harsh crtitism applying the doctrine to especially cases concerning the violation of Article 9- freedom of thought, conscience and religion and Article 10- freedom of expression, since it seems to lack standards in application. In this study, the European Court of Human Rights' controversial application of margin of appreciation doctrine to freedom of religion and freedom of expression will be addressed. The discussion will seek to analyse the reasons behind the Court's significant discretion affording to Contracting States when Article 9 and Article 10 cases are in question.
\end{abstract}

Keywords: Margin of Appreciation, Public Morality, Fundamental Rights, The ECtHR

Arş. Gör. Dr., Kocaeli Üniversitesi, İktisadi ve İdari Bilimler Fakültesi, Uluslararası İlişkiler Bölümü, itir.aladagg@gmail.com

Bu makale iThenticate sistemi tarafından taranmıştır.

Makale Gönderim Tarihi: 31.07.2015

DOI: $10.17550 /$ aid.43200 
$\ddot{O} z$

Avrupa İnsan Hakları Mahkemesi'nin Sözleşmeci Devletler'e kamu yararı ve bireylerin çıkarları arasında denge kurma firsatını vermesi "takdir hakk doktrini" olarak adlandirllmaktadır. Ne yazlk ki, Mahkeme özellikle Made 9- düşünce, vicdan ve din özgürlüğü ve Madde 10- ifade özgürlüğü ile ilgili davalara doktrini uygularken, herhangi bir standard yokmuş gibi göründüğ̈̈ için,sert eleştirlerle karşılaşmaktadır. Bu çalışmada, Avrupa Insan Hakları Mahkemesi'nin din özgürlüğü ve ifade özgürlügüne takdir hakkı doktrinini tartışmalı olarak uygulaması ele alınacaktır. Tartı̧̧ma, Mahkeme'nin Sözleşmeci Devletler'e Madde 9 ve Madde 10 davaları söz konusu olduğunda belirgin bir takdir hakkı tanımasının arkasindaki nedenleri analiz etmeye çalışacaktır.

Anahtar Kelimeler: Takdir Hakk, Kamu Ahlakı, Temel Haklar, AïHM 


\section{Introduction}

Since 1959, the European Court of Human Rights (ECtHR, the Court) has been tasked with ensuring that the Council of Europe's (the CoE) member states stick to fundamental rights. The $\mathrm{CoE}$ is separate from the European Union (EU), but the latter is expected to accede to the European Convention on Human Rights (ECHR, the Convention, The European Convention) and join the Council of Europe as an independent legal entity. As a result of acceding to the Convention, the EU will be integrated into the fundamental rights protection system of the ECtHR. Regarding the EU's leading role of promoting and defending human rights, democracy and the rule of law within its borders and in its relations with non- EU countries, its accession to the $\mathrm{CoE}$ is a very substantial move towards the transnationalism of human rights. On the other hand, being the only judicial authority of the CoE, The Court is noted as the most successful human rights institution, especially when hearing and concluding the cases concerning the violation of the non-restrictable four articles-(Article 2-right to life, Article 3- not to be subjected to torture or to inhuman or degrading treatment or punishment, Article 4 (1)- not to be held in slavery or servitude, Article 7 (1)- not to be convicted for conduct which was not an offence under national or international law at the time it occurred and not to have a heavier penalty imposed for an offence than that which was applicable when the offence was committed). However, having 47 members from very different socio- cultural backgrounds affects the CoE's and the ECtHR's efforts to establish transnational human rights standards. The Court has faced harsh criticism about interpreting Article 9 and Article 10 too narrowly. Being implied in European Convention, like majority of other fundamental rights, freedom of thought, conscience and religion and freedom of expression is subject to certain restrictions such as being in accordance with domestic law and complying with necessary regulations in a democratic society, which seem to be the deficits of Article 9.

Legislators of the European Convention on Human Rights aimed to establish a transnational protection system to end state dominance over fundamental human rights and dignify humane values where they are supposed to be. Thence, the Convention, apart from its contempo- 
raries, maintains a system of guarantee by means of a well- established control mechanism (Okay Tekinsoy, 2011: 66). Case law is one of the most important features of this mechanism and as the European Court of Human Rights has strongly stated that the Convention is a "constitutional instrument of European public order" (Loizidou v. Turkey, 1996). Unfortunately, the Court has not describe the meaning or features of the European public order, yet. Does it refer to have common standard values and live up to them, or, live together with different understanding of rights and just to maintain minimum standards and leaving rest to the Contracting Parties? As the Court having 47 States as members under its jurisdiction, implementation and application of fundamental rights in a uniform pattern become an issue from time to time. ECtHR using the margin of appreciation mechanism gives States a certain sphere for discretion to override different interpretations of fundamental rights in the Convention and Additional Protocols. The problem is, the Court lacks standarts in granting appreciation to States; its application varies from one State to another and also one fundamental right to another. That means, some States are more "independent" on the interpretation of fundamental rights. More importantly some rights seems more "expendable" for the good of the public or public interest. Amongst those "expendable" rights, freedom of religion- Article 9 and freedom of expression- Article 10 hold the first places. The main reason behind the Court's policy not to intervene these kind of cases (undoubtedly to some extent) is Article 9 and 10 considered as public morality issues and evaluated as directly connected to States' public policies. In this article, first we will describe the mechanism of margin of appreciation, then analyse its application in some former and more recent cases concerning the violation of Article 9 and Article 10 of the Convention,also known as public morality cases.

\section{Margin of Appreciation Doctrine in General}

In the jurisprudence of the European Court of Human Rights, "margin of appreciation" basically means judicial discretion granted to Contracting States on issues directly related to States' public policies or public interests. In other words, it is the degree of deference afforded to states in deciding on the implementation and application of rights guaranteed in the European Convention. It acts both as a standard of 
review and as a substantive norm for interpreting the Convention. Margin of appreciation "doctrine" stands on three different "principles". First, the principle of proportionality is employed to constrain the power of Member States over the rights of individual persons (Arai- Takahashi, 2001: 2). States can only limit fundamental rights guaranteed in the Convention, when it is presciribed by law with legitimate aims and when it is necessary in a democratic society. That leads us to the second principle; according to the principle of subsidiarity, the Court's role on the protection of fundamental rights and freedoms are secondary. In other words, as mentioned in the ground breaking Handyside case; "it is in no way the Court's task to take place of the competent national courts but rather to review the decisions they delivered in the exercise of their powerof appreciation" (Handyside v. UK, 1976). The Court's task is to act as a supervisor to national courts, it has no duty to decide on behalf of them. In this respect, the Convention's and the Court's protection system is subsidiary (Tümay, 2008: 203). The principle of subsidiarity derives from the idea that national authorities can reach the best solution considering their closer connection to the issue before them comparing to an international judge (Handyside v. UK, 1976). Accordingly, third principle, principle of review puts the Court as a reviewing authority, not a final court of appeal or fourth instance appeal (Arai- Takahashi, 2001: 235).

Despite of the principles the doctrine stands on, the Convention emphasizes the importance of the ECtHR in the protection system. For example, Article 1 of the European Convention of Human Rights impose the Contracting States to secure the rights and freedoms defined in the Convention to everyone, Article 19 of the ECHR reads the ECtHR is the only authority that this obligation be observed. That is to say, according to Article 19 of the European Convention, the margin of appreciation of States limited to the Court's responsibility to protect individual rights. By acceding the European Convention of Human Rights and joining the Council of Europe, the High Contracting Parties agreed that the European Court of Human Rights gives the final ruling on whether a restriction is compatible with rights guaranteed by the Convention. In the well- known Handyside ve United Kingdom case, the ECtHR emphasised its role in the margin of appreciation system eminently; 
"The domestic margin of appreciation thus goes hand in hand with European supervision. Such supervision concerns both the aim of the measure challenged and its necessity; it covers not only the basic legislation but also the decision applying it, even one given by an independent court" (Handyside v. UK, 1976).

From a different point of view, as Howard Yourow defines the doctrine in his noteworthy study, States should evaluate the margin of appreciaton doctrine as "freedom to act" or "the latitude of deference or error" (Yourow, 1996: 13). Yourow states that in margin of appreciation mechanism, the ECtHR will allow national legislative, executive, administrative and judicial bodies to act and decide from their point of view before it rules a violation (Yourow, 1996: 13). In this respect, the margin of appreciation doctrine, as the way it is used by the European Court of Human Rights, is Contracting States discretion in enacting and enforcing their law under international supervision of the Court.

The basic principle of margin of appreciation doctrine is, the assumption that national judge or state authorities are in a beter position than international judge to resolve the conflict in question (Tümay, 2002: 202). This controversial presumption strengthens contracting states' arguments, especially violation of Article 9 and Article 10 of the Convention are at stake. Yet, before analysing these special conditions it is beter to study the doctrine and give furthe information about its application process. Officially, the term "margin of appreciation" is not mentioned anywhere in the European Convention of Human Rights (Brauch, 2005: 116). In addition, the Court does not (have to) mention the term explicitly while deciding in favor of a state restriction. In general, application of margin of appreciation "clause" derives from second paragraphs of the articles in the Convention. The legislators of the ECHR, usually, describe the fundamental right to be protected in the first paragraph of any given article. Then, again generally, in the second paragraphs, the Convention explains the conditions which Contracting States can limit or restrict that right. Regarding the articles we intend to survey, this pattern follows as well. In the first paragraph of Article 9, the Convention states everyone's right to freedom of thought, conscience and religion and indicates that this right includes freedom to change religion or belief, either alone or in community with others 
and in public or private (CoE, 1950: CETS 005- Article 9 Paragraph 1). As mentioned in Article 9, this right also considers the manifestation of one's religion or beliefs, in worship, teaching, practice and observance (CoE, 1950: CETS 005- Article 9 Paragraph 1). After illustrating the scope of the right, Paragraph 2 refers the limitations to freedom of religion. As the Paragraph 2 of Article 9 reads; "Freedom to manifest one's religion or beliefs shall be subject only to such limitations as are prescribed by law and are necessary in a democratic society in the interests of public safety, for the protection of public order, health and morals, or for the protection of the rights and freedoms of others" (CoE, 1950: CETS 005- Article 9 Paragraph 2). Undoubtfully, the instruments and measures to protect public order and morals differs from one State to another since the understanding of "public order" varies in multiple ways. This is also the basic fundamental of the Court granting a certain margin of appreciation to Contracting States. The intention is to respect diversity, but it seems to be undermining the universality principle of human rights.

Similarly, First Paragraph of Article 10 states everyone's right to freedom of expression (CoE, 1950: CETS 005-Article 10 Paragraph 1). It describes the right as including freedom to hold opinions and to receive and impart information and ideas without interference by public authority and regardless of frontiers (CoE, 1950: CETS 005-Article 10 Paragraph 1). After portraying freedom of expression in a very general and ambigious manner, the Convention is much more specific with the restrictions. In the Second Paragraph of Article 10, as it follows in the Convention, freedom of expression in general, comes with duties and responsibilities so that it can be subject to such formalities, conditions, restrictions and penalties as soon as they are prescribed by law and are necessary in a democratic society (CoE, 1950: CETS 005- Article 10 Paragraph 2). The circumstances legitimise those restrictions and penalties attributed in the scope of freedom of expression are "... in the interest of national security, territorial integrity or public safety, for the prevention of disorder or crime, for the protection of health and morals, for the protection of reputation or rights of others, for preventing disclosure of information received in confidence, or for maintaining the authority and impartiality of judiciary" (CoE, 1950: CETS 
005-Article 10 Paragraph 2). Once again, like the preceding article and many other, Contracting States discretionary rights emerge from the second paragraph of the given article and is available to interpret broadly. The concept of "morals" is distinct in the jurisdiction area of the Council of Europe which means the Court, if willing to apply margin of appreciation doctrine, is supposed to hear every alleged violation of Article 10 from a different point o view. In other words, by applying margin of appreciation doctrine, the ECtHR accepts right to freedom of expression has different scopes in Turkey and France. Consequently, "transnational protection system" seems like just a good wish and state domination over fundamental human rights remains still.

\section{Not That Much Fundamental: A Wide Range of State Discretion to Freedom of Expression and Freedom of Conscience and Religion}

The logic behind the margin of appreciation doctrine is to promote diversity and "introduce flexibility in universal human rights standards in response to non- Western particularist human rights discourse" (Brems, 2001: 423; Moral, 2006: 622). These "good intentions" seem to went a step further. Regarding the Court excessive, in some points unreasonable case load and considering it takes nearly five years to the ECtHR to close a case, leaving Member States to solve some problems on their own is undoubtfully understandable. However, "understandable" is not always the best thing to do. The Court's policy not to intervene in puplic policy matters overdoes and goes hand in hand with human rights violations. The ECtHR grants a little bit more discretion to Contracting States especially in cases concerning the violation of Article 9 and Article 10. Regarding the common phrase "public morality" used for Article 9 and Article 10 cases, their violations are consequently closely concerned. Public morality is a term used to explain laws and public actions addressing moral conduct according to moral values inherent in that society. More importantly, public morality is always a step beyond the considerations of law and public policy (George, 2000: 17). The importance of the term derives from the fact that public morality does not refer to the obligations of one individual to another, rather it involves our responsibilities and commitments to live in a society that has its own values inherently. In the jurisprudence of ECtHR, Contracting 
Parties seem to have a wide margin of appreciation in assessing the need to interfere with the exercise of freedom of reigion or freedom of expression for the protection of morals (Prebensen, 1998: 17). Accordingly, Member States dangerously started to treat these rights as expendable, not so vital and not so fundamental. Regarding the universal principle that all human rights are of equal importance, application of margin of appreciation doctrine needs to be re-evaluated. In this part of our study, we will look up to some cases the Court referred to the margin of appreciation doctrine, explicitly or implicitly, whether or not it ruled in favor of the respondent State. Then, in Conclusion Part, we will try to analyse these applications in terms of human rights.

\section{Application of Margin of Appreciation to Freedom of Religion (Ar- ticle 9)}

Kokkinakis v. Greece; Despite the European Convention of Human Rights recognizes the right to manifest one's religion or belief, according to Greek domestic law proselytising is a crime requires penalty. (http://www.state.gov/documents/organization/171697.pdf). Mr. Kokkinakis, a Jehowah's Witness, after trying to convince a local Orthodox Church member tergiversate, was convicted for proselytism. (Independent, 19 June 1993). He appealed to the ECtHR claiming the violation of Article 7- no punishment without law, 9- freedom of thought, conscience and religion, 10- freedom of expression and 14- prohibition of discrimination (Kokkinakis v. Greece, 1993). The Court found it unnecessary to examine the file under Article 10 and 14, and also decided that Applicant's claims under Article 7 are not really clear (Kokkinakis v. Greece, 1993). About Article 9, the Court agreed on the aim of the domestic law, it was prescribed by law and consistent with the Convention it has a legitimate aim to protect the rights and freedoms of others (Edge, 1998: 680). However, the application of the domestic law to Mr. Kokkinakis was found excessive and not necessary in a democratic society. The Court holds there was a breach of Article 9 by six votes to three. Eventough the decision was in favor of the applicant, Kokkinakis case is important since the Court emphasized the necessity of the measures taken by the State. In addition, the Court referred to margin of appreciation in its ruling, mentioning that; 
"The Court has consistently held that a certain margin of appreciation is to be left to the Contracting States in assessing the existence and extent of the necessity of an interference, but this margin is subject to European supervision, embracing both the legislation and the decisions applying it, even those given by an independent court. The Court's task is to determine whether the measures taken at national level were justified in principle and proportionate" (Kokkinakis v. Greece, 1993).

McGuinness v. United Kingdom: Mr. James Martin Pacelli McGuinness is still a well- known Irish Republician Sinn Féin politician. His application to the ECtHR was about the oath he had to take after being elected for the United Kingdom Parliament. According to the domestic law, elected members of the Parliament are (still) required to take the oath of allegiance to the British Monarchy as a condition to take their seats (http://www.parliament.uk/site-information/glossary/ oath-of-allegiance/). Since the beginning of his campaign in line with official Sinn Féin policy, McGuinness refused to take the oath. Consequently, in accordance with the UK legislation, he could not take his seat (Tümay, 2008: 207) and "he has been denied to access the facilities available elected representatives" (McGuinness v. United Kingdom, 1999). The applicant complained UK to the ECtHR, claiming the violation of Article 14 (prohibition of discrimination), Article 9, Article 10 and Article 3 of Protocol No 1 (right to free elections) (McGuinness v. United Kingdom, 1999). Setting an example for the future complaints, the Court declared the application inadmissible in all matters. The Judges unanimously rejected the applicant's complaints under the articles named above as being manifestly ill- founded (McGuinness v. United Kingdom, 1999). The ECtHR emphasised the margin of appreciation once again, saying;

"The Court recalls that in their internal legal orders, the Contracting States have a wide margin of appreciation in subjecting the rights to vote and stand for election to prescribed conditions" (McGuinness v. United Kingdom, 1999).

The Court also noted that the applicant was aware of the conditions required to become a Parliament Member when he decided to 
run for the elections. In addition, ECtHR values attaching such conditions as an integral part of constitutional order of the respondent State (McGuinness v. United Kingdom, 1999). As a result, respondent State has given a wide degree of deference in a matter considered directly related to integral conceptualization of necessary means in a democratic society (Tümay, 2008: 208).

Leyla Şahin v. Turkey: Ms. Şahin was a medical student in İstanbul University who was refused, like all other female students prefer religious clothing, to access lectures or examinations while wearing headscarf after the ruling of 1998 in Turkey (Press Unit - Religious Symbols and Clothing, 2015: 4). She filed a complaint aginst Turkey, claiming the violation of Article 9, stressing that she considered it her religious duty to wear Islamic headscarf (Leyla Şahin v. Turkey, 2005). The Grand Chamber of the European Court of Human decided in favor of the Rebuplic of Turkey, found no violation of freedom of religion. Similar to the Mcguinness Case, the Court indicates that, the applicant was aware of the rule when she entered the university (Leyla Şahin v. Turkey, 2005). The Grand Chamber, considered wearing headscarf as the manifestation of religion and ruled that "there was a legal basis in Turkish law for the interference with the applicant's right to manifest her religion, as the Turkish Constitutional Court had ruled before that wearing headscarf in universities was contrary to the Constitution" (Press Unit- Religious Symbols and Clothing, 2015: 3). The Court appraised Turkey's implementation within the limits of margin of appreciation, found the interference "necessary in a democratic society". Finally, the ECtHR stated that, the impact of wearing the Islamic headscarf might have on those who chose not to wear it, had to be taken into consideration (Press Unit - Religious Symbols and Clothing, 2015: 4).

S.A.S. v. France: The applicant is a French national. After the law prohibiting the concealment of one's face in public places entered into force on 11 April 2011, she is not allowed to wear full- face veilin public (S.A.S. v. France, 2014). The applicant insisted that wearing the burqa and niqab is a requirement of her religious faith, culture and personal convictions and added no one is putting pressure on her in this manner. S.A.S. also added her aim was not to annoy others but to feel at inner peace with herself (Press Unit- Religious Symbols and Clothing, 
2015: 6). In accordance with these statements, she complained France to the ECtHR claiming her rights under Article 8 (right to respect for family and private life) and Article 9 (right to respect freedom of thought, conscience and religion) are violated (S.A.S. v. France, 2014).

The Court ruled that there had been no violation of any rights. In its remarkable decision, the Court stated that as conditions of "living together" prohibitions can be used. The Court held, once again, the State has a "wide margin of appreciation" as regards this general policy question on which there were significant differences of opinion (Press Unit- Religious Symbols and Clothing, 2015: 7). Although the ban in question had specific negative effects on the situation of practising Muslim women, the Court stated that the measure had an objective and reasonable justification (Press Unit- Religious Symbols and Clothing, 2015: 4).

Lautsi and Others v. Italy: Mrs. Lautsi is parent living in Italy with her family and wished to bring up her children according to the principle of secularism. She and her husband regarded the presence of religious symbols in the classrooms, namely crucifixes in this case, contrary to their right to freedom of thought, conscience and religion (Press Unit- Religious Symbols and Clothing, 2015: 1). Even they brought administrative proceedings, they failed and their application was rejected in all degrees by the Italian authorities (Press Unit- Religious Symbols and Clothing, 2015: 1). Eventually, they filed a complaint before the ECtHR claiming the breach of Article 9 of the Convention and Article 2 (right to education) of Additional Protocol 1 (Lautsi and Others v. Italy, 2011).

The Court, in its Grand Chamber meeting, held there had been no violation at all. The judges once again emphasized the notion of state discretion stating that the presence of religious symbols in the classrooms falled within the "margin of appreciation" of the State, regarding that there was no European consensus on that issue (Press Unit- Religious Symbols and Clothing, 2015: 1). According to the Court, the crucifixes in State- school classrooms conferred the majority religious group in the society a public visibility, they were not used in process of indoctrination, there had been no signs of intolerance to the 
other religious groups, non- believers or who held non- religious philosophical convictions (Press Unit- Religious Symbols and Clothing, 2015: 1).

\section{Application of Margin of Appreciation to Freedom of Expression (Article 10)}

Otto- Preminger Institut v. Austria; Otto- Preminger Institut was a non- profit organization, arranging entertainment activities, especially by means of audiovisual media (Edge, 1998: 681). According to the case file in ECtHR their activities include operating a cinema called "Cinematograph" in Innsbruck (Otto- Preminger Institut v. Austria, 1994). The applicant association announced the public showings of the movie Das Liebeskonzil (Council in Heaven) in its facilities. (https:// www.article19.org/resources.php/resource/2613/en/otto-premingerinstitut-v.-austria). According to the domestic law, entry would be limited to persons over 17; a local newspaper anounced the title of the film and the showtimes without giving any particular information neither about its content nor about the age limit (https://www.article19.org/ resources.php/resource/2613/en/otto-preminger-institut-v.-austria). At the request of the Innsbruck diocese of the Roman Catholic Church, the public prosecutor started criminal proceedings for disparaging religious doctrines (http://merlin.obs.coe.int/iris/1995/1/article1.en.html). The film was seized after it was shown in a very small group of people and could not make any public showings. The Regional Court ordered the forfeiture of the film (Otto- Preminger Institut v. Austria, 1994). Otto- Preminger Institut brought the case before the Court claiming the breach of freedom of expression under Article 10 of the Convention (Otto- Preminger Institut v. Austria, 1994).

Once again the main ground the Court established its decision was whether the infringement of the guarantee under the Article was justified as being in pursuance of a legitimate aim and necessary in a democratic society (Edge, 1998, 681). The respondent State argued that its actions were aimed to protect the rights and freedoms of the others given that the movie was a satirical tragedy set in Heaven. The Court agreed with the defendant and also found seizure and fortfeiture of the movie proportionate regarding the aim "protection of the rights 
of the others" (Case of Otto- Preminger Institut v. Austria, 1994: Paragraph 56- 57).

In Otto- Preminger Institut Case, the Court's rationalisation of the positive relation between the morals and application of margin of appreciation is of vital importance. As the ECtHR follows;

"As in the case of "morals" it is not possible to discern throughout Europe a uniform conception of the significance of religion in society; even within a single country such conceptions may vary. For that reason it is not possible to arrive at a comprehensive definition of what constitutes a permissible interference with the exercise of the right to freedom of expression where such expression is directed against the religious feelings of others. A certain margin of appreciation is therefore to be left to the national authorities in assessing the existence and extent of the necessity of such interference" (Case of Otto- Preminger Institut v. Austria, 1994: Paragraph 50).

As can be seen, when public morals are at stake, the Court gives credit to the Contracting States to decide where to start and finish freedom of expression. It is important to mention that, unfortunately, the decision of Otto- Preminger Instutit, set an example for States for the future interferences.

Wingrove v. United Kingdom; Just like Otto- Preminger Institut, the case was about the non- allowance of public showings of a satirical movie named "Visions of Ecstasy". The British Board of Film Classification rejected to classify the video, because of being blasphemous and against the criminal law (Edge, 1998: 683). The director of the movie Nigel Wingrove, applied to the European Court of Human Rights and claimed the violation of his freedom of expression under Article 10. The Court rules in favor of the respondent State, and decided the interference pursued an legitimate aim;

“... intended to supress behaviour directed against objects of religious veneration that is likely to cause justified indignation amongst believing Christians. The application of this law in the present case was intended to protect the rights of citizens not to be insulted in their religious feelings" (Wingrove v. United Kingdom, 1996: Paragraph 47). 
Again in Wingrove case, the ECtHR insistedly pointed out the importance of margin of appreciation in public morality issues;

“... a wider margin of appreciation is generally available to the Contracting States when regulating freedom of expression in relation to matters liable to offend intimate personal convictions within the sphere of morals or, especially, religion. Moreover, as in the field of morals, and perhaps to an even greater degree, there is no uniform European conception of the requirements of "the protection of the rights of others " in relation to attacks on their religious convictions." (Wingrove v. United Kingdom, 1996: Paragraph 58).

To this end, the Court once again held its role as subsidiary while deciding on vulnerable puclic morality cases. As established in Handyside ruling, "By reason of their direct and continuous contact with the vital forces of their countries, State authorities are in principle in a better position than the international judge to give an opinion on the exact content of these requirements as well as on the "necessity" of a "restriction" or "penalty" intended to meet them" (Handyside v. UK, 1976: Paragraph 48). The European Court of Human Rights seems to be following the motto since then.

Balsyté- Lideikiené v. Lithuania: Similar case to Handyside, the applicant was found guilty of publishing and distributing of a harmful issue according to the local law. The difference is the publication in question, "Lithuan Calendar 2000" was regarded as promoting ethnic hatred. After finding guilty according to the Code on Administrative Offences, the applicant was issued with an administrative warning and the unsold copies of the calendar were confiscated (Press Unit- Hate Speech, 2015: 8). She applied to the ECtHR claiming Lithuania breached her freedom of expression (Balysté- Lideikiené v. Lithuainia, 2008).

The Court held that the content of the applicant's publication could incite hatred against Jews and Poles and that possibility enables Lithuanian authorities to adopt required measures, this had been regarded as one of the main principles of margin of appreciation application (Balysté- Lideikiené v. Lithuainia, 2008). The majority of the judges concluded that in the case before them the State Authorities did not 
exceed the limits of their margin of appreciation (Balysté- Lideikiené v. Lithuainia, 2008). Consequently, the Court decided there had been no violation of Article 10.

Vejdeland and Others v. Sweden: The applicants distributed in an upper secondary school leaflets stereotyping homosexuality which the domestic courts found offensive. Some of the allegations on the leaflets were accusing homosexuals having "a morally destructive effect on the substance of society" and being responsible for the development of HIV and AIDS (Press Unit- Hate Speech, 2015: 5). The applicants defended themselves by stating that their primary aim was to call attention to the lack of objectivity in the education of Swedish schools, they did not mean to express contempt to homosexuals as a group (Press Unit- Hate Speech, 2015: 5).

The Court decided that these statements are highly discriminative and found the interefence of Swedish authorites as necessary in democratic society for the protection of reputation and rights of others (Vejdeland and Others v. Sweden, 2012). Eventhough the Court did not explicitly referred to "margin of appreciation", means taken to maintain a democratic society are considered within the limits of state discretion. Accordingly, the Court held there had been no violation of Article 10 (Vejdeland and Others v. Sweden, 2012).

I.A. v. Turkey: In an another publication case, the applicant once again was a publisher, who published a book about theological and philosophical issues. He was charged with insulting "God, the Religion, the Prophet and the Holy Book" by the İstanbul public prosecutor and the court of first instance found him guilty (CoE, 2007: 95). The applicant appealed to the Court of Cassation, it also upheld the judgment (İ.A. v. Turkey, 2005).

Once again, the Court held there had been no violation of Article 10. The ECtHR emphasized "... those who chose to exercise the freedom to manifest their religion, irrespective of whether they did so as members of a religious majority or a minority, could not reasonably except to be exempt from all critism" (Press Unit- Hate Speech, 2015: 10). While asking tolerance and acceptation, the Court regarded the publication before it provocative and as an abusive attack on the Prop- 
het of Islam. Accordingly, the Court found the measure in question had met a" pressing social need" (İ.A. v. Turkey, 2005).

\section{Conclusion}

In 1949, when founding fathers established the Council of Europe, the humble aim was to maintain and protect the peace founded on the values of human rights, democracy and the rule of law. After almost 70 years, it won't be an exaggration to cite the Council as one of the most succesful human rights organizations. Moreover, in spite of its regional character, the Organization undertakes the duty to transnationalise human rights and humane values. As of 2015, the Council of Europe and its judicator power the European Court of Human Rights have their jurisdiction over 47 Member States, which means, 820 million individuals are under the protection of the European Convention.

However, being responsible from that wide range of area forces the ECtHR to maintain the balance between the Member States and individuals. Having 47 members from different socio- cultural backgrounds, the Court struggles with different conceptalisation of fundamental rights. Instead of setting standards in application of the rights guaranteed under the Convention and Additional Protocols, the ECtHR prefers to grant Contracting States a high margin of appreciation. By avoiding to intervene in matters directly related to public policy/ public interest of the States, the Court (so- called) support the diversity and reconcile the concept of human rights with "non- Western" members of the Council. Unfortunately, the thin red line between avoiding to intervene internal affairs and overlooking human rights violations becomes more blurred day by day. Evaluating the case- law, the Court rules in favor of the States by using the margin of appreciation, especially in cases about freedom of religion and freedom of expression. Accordingly, these rights become vulnerable, and individuals in need of protection from these points are forced towards possible exploitations. The Court must immediately leave the obviously political use of the margin of appreciation doctrine, or at least restrict it within a set of rules. Untill then, European public order for human rights stands far away from here. 


\section{References}

\section{Books}

Arai- Takahashi, Y. (2001). The margin of appreciation doctrine and the principle of proportionality in the jurisprudence of the ECHR. New York- USA: Intersentia.

Brems, E. (2001). Human rights: Universality and diversity. The Hague- The Netherlands: Kluwer Law International.

Council of Europe (2007). Freedom of expression in Europe. Strasbourg- France: Council of Europe Publishing.

\section{Articles}

Brauch, J. (2005). The margin of appreciation and the jurisprudence of the European Court of Human Rights: Threat to the rule of law. Columbia Journal of European Law, 11, 113- 150.

Edge, P. (1998). The European Court of human rights and religious rights. The International and Comparative Law Quarterly, 47 (3), 680-687.

George, R. P. (2000). The concept of public morality. American Journal of Jurisprudence, 45 (1), 17- 31.

Moral, I. (2006). The increasingly marginal appreciation of marginof-appreciation doctrine. German Law Journal, 7 (6), 611- 624.

Okay Tekinsoy, Ö. (2011). Avrupa kamu düzeni kavramı. Hacettepe Üniversitesi Hukuk Fakültesi Dergisi, 1 (1), 66- 79.

Prebensen, Soren C. (1998). The margin of appreciation and article 9, 10, 11 of the convention. Human Rights Law Journal, 19, 13- 17.

Tan, Ying Hui (1993). Law Report/ Greek Case Violated Religious Freedom: Kokkinakis v. Greece- European Court of Human Rights, Strasbourg 25 May 1993, Independent (published on 16 June 1993- accession via website http://www.independent.co.uk/news/uk/law-report-greek-case-violated-religiousfreedom-kokkinakis-v-greece-european-court-of-humanrights-1492004.html )

Tümay, M. (2008). The "Margin of Appreciation Doctrine" developed by the case law of the European Court of Human Rights. Ankara Law Review, 5 (2), 201- 234. 
Yourow, H. C. (1996). The margin of appreciation doctrine in the dynamics of European Human Rights Jurisprudence. Connecticut Journal of International Law, 3, 111- 128.

\section{Documents}

Council of Europe, "Convention for the Protection of Human Rights and Fundamental Freedoms", (adopted 4 November 1950- entry into force 3 September 1953), London, CETS 005.

European Court of Human Rights' Press Unit, “Factsheet- Hate Speech", Strasbourg- France, June 2015

European Court of Human Rights' Press Unit, "Factsheet- Religious Symbols and Clothing", Strasbourg- France, June 2015

\section{Cases}

Balysté- Lideikiené v. Lithuainia, Application No. 72596/01, Judgment 4 November 2008 Handyside v. UK, Application No. 5493/72, Judgment 7 December 1976

İ.A. v. Turkey, Application No. 42571/ 98, Judgment 13 September 2005

Kokkinakis v. Greece, Application No. 14307/88, Judgment 7 May 1993

Lautsi and Others v. Italy, Application No. 30814/06, Judgment 18 March 2011

Leyla Şahin v. Turkey, Application No. 44774/98, Judgment 10 November 2005

Loizidou v. Turkey, Application No. 15318/89, Judgment 18 December 1996

McGuinness v. United Kingdom, Application No. 39511/98, Judgment (Decision on Admissibility 8 June 1999)

Otto- Preminger Institut v. Austria, Application No. 13470/87, Judgment 20 September 1994

S.A.S. v. France, Application No. 43835/11, Judgment 26 June 2014

Vejdeland and Others v. Sweden, Application No. 1813/07, Judgment 9 May 2012

Wingrove v. United Kingdom, Application No. 17419/90, Judgment 25 November 1996 


\section{Websites}

http://merlin.obs.coe.int/iris/1995/1/article1.en.html (latest access September 2015)

http://www.parliament.uk/site-information/glossary/oath-ofallegiance/ (latest access September 2015)

http://www.state.gov/documents/organization/171697.pdf (latest access September 2015)

https://www.article19.org/resources.php/resource/2613/en/ottopreminger-institut-V.-austria (latest access September 2015) 